\title{
Drug-Related Problems in the transitional care of the elderly from hospital to home
}

\author{
Problemas Relacionados a Medicamentos na transição de idosos do hospital para casa \\ Problemas Relacionados com los Medicamentos en la transición de ancianos del hospital para casa
}

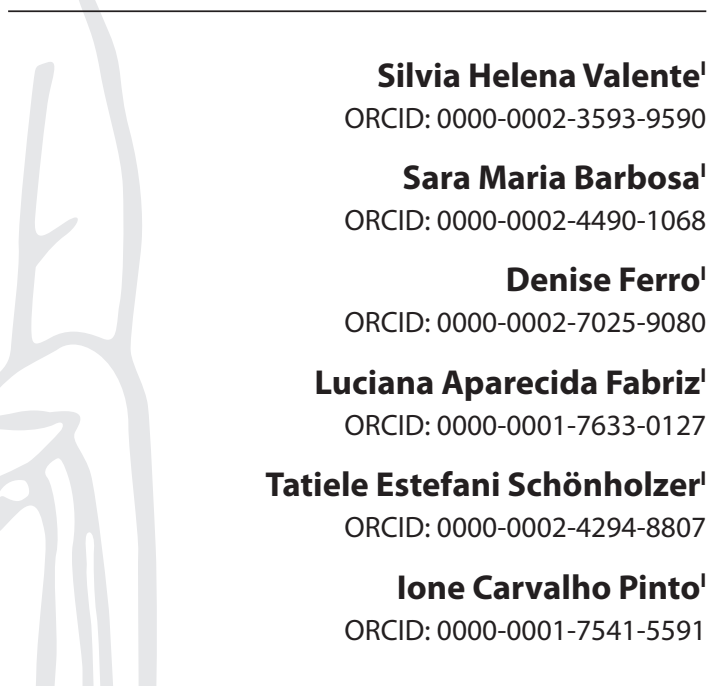

'Universidade de São Paulo. Ribeirão Preto, São Paulo, Brasil.

How to cite this article:

Valente SH, Barbosa SM, Ferro D, Fabriz LA,

Schönholzer TE, Pinto IC. Drug-Related Problems in the transitional care of the elderly from hospital to home. Rev Bras Enferm. 2019;72(Suppl 2):345-53. doi: http://dx.doi.org/10.1590/0034-7167-2018-0848

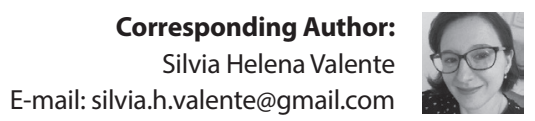

Submission: 02-05-2018 Approval: 03-26-2019

\begin{abstract}
Objective: To identify the knowledge produced on Medication-Related Problems in the transitional care of the elderly from hospital to home. Method: Integrative review of the literature data, organized in six stages: guiding question; establishment of inclusion and exclusion criteria; extraction of data; analyze; interpretation of results; and presentation of the review. Articles were considered among 2002 and 2017, in Portuguese, English, and Spanish, in the databases LILACS, MEDLINE, CINAHL and EMBASE. Results: 10 studies were selected and analyzed. They were categorized by subject and identified in three themes: Medication Discrepancy and Reconciliation (40\%); Adhesion to Medication (30\%); and Adverse Drug Events (30\%). Final considerations: Drug-Related Problems in the transitional care of the elderly from hospital to home, were presented as a relevant theme for nursing, involving complex issues related to care. Drug reconciliation was evidenced as a coherent and effective strategy in home care transitions for the elderly. Descriptors: Transitional Care; Medication Therapy Management; Patient Care Planning; Health of the Elderly; Nursing Care.
\end{abstract}

\section{RESUMO}

Objetivo: identificar o conhecimento produzido sobre Problemas Relacionados a Medicamentos na transição de idosos do hospital para casa. Método: revisão integrativa da literatura, organizada em seis etapas: pergunta norteadora; estabelecimento de critérios de inclusão e exclusão; extração dos dados; análise; interpretação dos resultados; e apresentação da revisão. Consideraram-se artigos entre 2002 e 2017, nos idiomas português, inglês e espanhol, nas bases de dados LILACS, MEDLINE, CINAHL e EMBASE. Resultados: foram selecionados e analisados 10 estudos. Categorizaram-se por assunto e identificaram-se três temas: Discrepância e Reconciliação de Medicamentos (40\%); Adesão ao Medicamento (30\%); e Eventos Adversos a Medicamentos (30\%). Considerações finais: os Problemas Relacionados a Medicamentos na transição de idosos do hospital para casa, apresentou-se como um tema relevante para a Enfermagem, envolvendo questões complexas relacionadas ao cuidado. A reconciliação de medicamentos foi evidenciada como estratégia coerente e eficaz nas transições de cuidado do idoso para casa.

Descritores: Cuidado Transicional; Conduta do Tratamento Medicamentoso; Planejamento de Assistência ao Paciente; Saúde do Idoso; Cuidados de Enfermagem.

\section{RESUMEN}

Objetivo: identificar el conocimiento producido sobre Problemas Relacionados con los Medicamentos en la transición de ancianos del hospital a casa. Método: la revisión integrativa de la literatura, organizada en seis etapas: pregunta orientadora; establecimiento de criterios de inclusión y exclusión; extracción de datos; análisis; interpretación de los resultados; y presentación de la revisión. Se consideraron los artículos entre 2002 y 2017, en portugués, inglés y español, en las bases de datos LILACS, MEDLINE, CINAHL y EMBASE. Resultados: se seleccionaron y analizaron 10 estudios. Se clasificaron por tema y se identificaron tres temas: Discrepancia y Reconciliación de Medicamentos (40\%); Adhesión al Medicamento (30\%); y Eventos Adversos a los Medicamentos (30\%). Consideraciones finales: los Problemas Relacionados con los Medicamentos en la transición de ancianos del hospital a casa, se presentó como un tema relevante para la enfermería, involucrando cuestiones complejas relacionadas con el cuidado. La reconciliación de medicamentos fue evidenciada como estrategia coherente y eficaz en las transiciones de cuidado del anciano a casa.

Descriptores: Cuidado de Transición; Administración del Tratamiento Farmacológico; Planificación de Atención al Paciente; Salud del Anciano; Atención de Enfermería. 


\section{INTRODUCTION}

Drug-Related Problems (DRPs) are events or circumstances involving drug therapy that actually or potentially interfere with the desired health outcomes. These problems can manifest themselves through discrepancies, errors, lack of adherence, polypharmacy, Adverse Drug Events (ADEs), among other difficulties related to drugs. When they occur in the elderly, during the transitional care from hospital to home, they represent a complex situation and can result in frequent rehospitalizations ${ }^{(1-2)}$.

DRPs can be a major challenge for Public Health in Brazil. According to a publication by the Ministry of Health $(\mathrm{MoH})$, it is estimated that 1.2 million to 3.2 million hospitalizations per year due to misuse of medicines. The cost, only for the Brazilian Unified Health System (SUS - Sistema Único de Saúde), of these problems, can reach 3.6 billion reais (Brazilian currency) per year ${ }^{(1,3)}$.

The elderly are more vulnerable to DRPs due to metabolic changes, chronic conditions, functional, and cognitive losses, as well as complex therapeutic regimens of drugs to which they are submitted. This population usually receives care from many professionals and frequently travels in different health services, becoming particularly susceptible to changes in drug therapy and care deficits in care transitions $s^{(2,4-5)}$.

Estimates by the Brazilian Institute of Geography and Statistics (IBGE - Instituto Brasileiro de Geografia e Estatística) predict that in 40 years, the elderly population will triple in Brazil, from 19.6 million in 2010 to 66.5 million people in $2050^{(6)}$. On average, 30\% of the elderly hospitalizations are linked to DRPs or toxic effects caused by drugs. There is consensus among experts that $50 \%$ to $70 \%$ of these problems could be avoided ${ }^{(1,3)}$.

Planned and systematized hospital discharges are one of the strategies to ensure continuity of care at home to reduce DRPs and avoid rehospitalizations. It ensures greater clarification for the elderly and their family about their new health condition and drug therapy ${ }^{(7-9)}$.

Hospital discharge is a time of great changes in the daily lives of the elderly. However, post-discharge guidelines usually happens only when the patient leaves the hospital mechanically and in a hurry. At the moment, many information is offered at the same time, making it difficult to understand the elderly, their relatives and/or caregivers ${ }^{(7-10)}$. Once at home, the elderly are faced with uncertainties about the new drug therapy and failures in the transitional care from hospital to home, which could lead to problems such as anxiety, and poor adherence to the medication ${ }^{(8,10)}$.

Nurses play an important role in providing care to the elderly. They are responsible, together with the multidisciplinary team, for the organization of the therapeutic plan for hospital discharge; preparation of users for self-care; and assurance of follow-up of the Primary Health Care (PHC). However, in practice, this process happens in a fragmented way, because there are failures in communication and there is no continuation of post-discharge care for other health services ${ }^{(7-11)}$.

The inadequate transitional care from hospital to home can lead to critical situations in the health of the elderly, comprising several DRPs, such as errors, ADE, lack of adherence and medication discrepancies, and poor quality of life. It may result in unnecessary hospital readmissions, inappropriate use of emergency services and dissatisfaction of patients and their caregivers, generating a burden on the health system ${ }^{(8,10,12)}$.

Thus, it is necessary to identify and know, in an in-depth way, DRPs in the transitional care of the elderly from hospital to home. The data obtained may contribute to the elaboration of strategies to modify practices and decision-making of the nurse, being able to collaborate with the public health policies of the country.

\section{OBJECTIVE}

To identify the knowledge produced on Drug-Related Problems (DRPs) in the transitional care of the elderly from hospital to home.

\section{METHOD}

\section{Ethical aspects}

The project was not submitted to the Research Ethics Committee (REC) because it is a review of published studies. No conflicts of interest were identified. All the authors of the articles that made up the IR were cited. All references were included in order to guarantee their intellectual property.

\section{Type of study}

This study uses Integrative Review (IR). It has the potential to enable several primary research methods to become a major part of Evidence-Based Practices. This method helps to identify results that contribute to professional decision-making, as well as to the development of future research ${ }^{(13-15)}$.

\section{Collection and organization of data}

Six stages of research were followed in order to strictly comply with all phases of an IR: guiding question selection; inclusion and exclusion criteria of studies establishment; information to be extracted from the selected articles definition; information analysis; interpretation of results; and review submission ${ }^{(13-15)}$.

The question of research was established: what were the knowledge produced in the literature about DRPs in the transitional care of the elderly from hospital to home?

Concurrently, the survey of the scientific productions was carried out from September to November of 2017, by two researchers, in the following databases: Latin American \& Caribbean Literature in Health Sciences (LILACS - Literatura Latino-Americana e do Caribe em Ciências da Saúde), Medical Literature Analysis and Retrieval System online (MEDLINE), National Center for Biotechnology Information, Cumulative Index to Nursing and Allied Health Literature (CINAHL), and EMBASE.

The descriptors obtained after consultation in the Health Sciences Descriptors (DECS - Descritores em Ciências da Saúde) and in the Medical Subject Headings (MESH), keywords, CINAHL, and Emtree terms were used in the databases, in an articulated way. Chart 1 shows the search strategy.

\section{Inclusion and exclusion criteria of studies}


Chart 1 - Search strategy and quantitative of articles found in databases and in the search directory, 2018

\begin{tabular}{|c|c|c|}
\hline Databases & Search Strategy & $\begin{array}{l}\text { Articles } \\
\text { Found }\end{array}$ \\
\hline MEDLINE & $\begin{array}{l}\text { Descritors (MeSH) and keywords - aged } \\
\text { OR elderly OR senior OR older people AND } \\
\text { transition care OR continuity of patient care } \\
\text { OR patient discharge AND medication errors } \\
\text { OR medication adherence OR medication } \\
\text { reconciliation OR drug-related side effects } \\
\text { and adverse reactions. }\end{array}$ & 239 \\
\hline LILACS & $\begin{array}{l}\text { Descritors (DeCS) and keywords in } \\
\text { Portuguese - idoso AND cuidado transicional } \\
\text { OR alta do paciente OR continuidade do } \\
\text { cuidado AND erros de medicação OR adesão à } \\
\text { medicação OR reconciliação de medicamento } \\
\text { OR efeitos colaterais e reações adversas } \\
\text { relacionadas a medicamentos. }\end{array}$ & 13 \\
\hline EMBASE & $\begin{array}{l}\text { Emtree terms and keywords - aged AND } \\
\text { chronic disease AND transition care; aged } \\
\text { AND chronic disease AND transition care } \\
\text { AND medication errors; aged AND chronic } \\
\text { disease AND transition care AND medication } \\
\text { adherence; aged AND chronic disease } \\
\text { AND transition care AND medication } \\
\text { reconciliation; aged AND chronic disease } \\
\text { AND transition care and drug-related side } \\
\text { effects and adverse reactions. }\end{array}$ & 48 \\
\hline CINAHL & $\begin{array}{l}\text { CINAHL titles and keywords - aged OR } \\
\text { elderly OR senior OR older people AND } \\
\text { transition care OR continuity of patient care } \\
\text { OR patient discharge AND medication errors } \\
\text { OR medication adherence OR medication } \\
\text { reconciliation OR drug-related side effects } \\
\text { and adverse reactions. }\end{array}$ & 58 \\
\hline
\end{tabular}

The selected articles were also classified according to the level of evidence proposed by Melnyk and Fineout-Overholt ${ }^{(17)}$, according to Chart 2.

Chart 2 - Evidence Hierarchy Classification System, 2018

\begin{tabular}{|c|l|}
\hline $\begin{array}{c}\text { Level of } \\
\text { Evidence }\end{array}$ & Evidence Source \\
\hline Level I & $\begin{array}{l}\text { Evidence regarding the systematic review or meta- } \\
\text { analysis of randomized controlled trials. }\end{array}$ \\
\hline Level II & Evidence from well-outlined randomized clinical trial. \\
\hline Level III & $\begin{array}{l}\text { Evidence obtained from well-outlined controlled trials } \\
\text { without randomization. }\end{array}$ \\
\hline Level IV & $\begin{array}{l}\text { Evidence from well-outlined cohort study and/or } \\
\text { control case. }\end{array}$ \\
\hline Level V & $\begin{array}{l}\text { Evidence of systematic reviews of descriptive and } \\
\text { qualitative studies; }\end{array}$ \\
\hline Level VI & Evidence from a single descriptive or qualitative study. \\
\hline Level VII & $\begin{array}{l}\text { Evidence from the opinion of authorities and/or reports } \\
\text { from expert committees. }\end{array}$ \\
\hline
\end{tabular}

Note: translated by Melnyk and Fineout-Overholt ${ }^{(17)}$.

\section{RESULTS}

The inclusion and exclusion criteria were applied. They were allowed to select 10 articles to compose the study sample, as shown in Figure 1.
The inclusion criteria used to compose the sample were original scientific productions that portray the researched subject, published from 2002 to 2017. The cut-off period was established, in view of the year of the first scientific publications on CT (Care Transitions) developed by Coleman et al., in $2002^{(16)}$, which presented the first guidelines for safe commutes from hospital to home. The articles were in Portuguese, English or Spanish; available electronically in full; original articles addressing home-to-hospital commutes in the critical 60-day post-discharge period of the elderly aged 60 years or older. Duplicate scientific productions were excluded in more than one database.

\section{Analysis and presentation of data}

From the composition of the sample, a database was prepared in Microsoft Office Excel software, 2010. This allowed to organize and to compile the following information of the selected studies: title; year and country; outlining and number of participants; interventions and outcomes. The data obtained were grouped into instrumental frames and categories. The results were interpreted based on Brazilian and international literature.

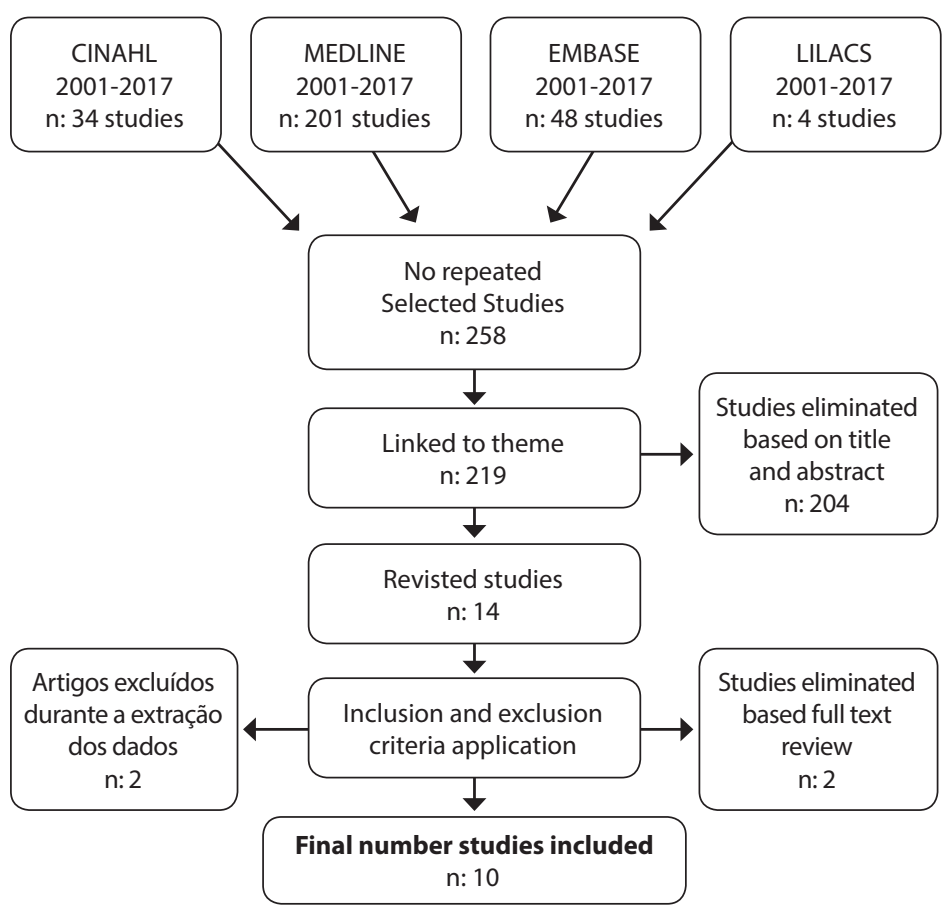

Figure 1 - Methodological course to select articles related to drug safety in the Care Transitions from hospital to home, 2018 
The highest proportion of articles (27\%) was published in 2010, followed by 2005 and 2008, with 18\% respectively. The country that most produced articles on DRPs in the commute from hospital to home was the United States, with five surveys (50\%), followed by Australia and Israel, with two articles, respectively (20\%), and Spain, with one article (10\%). There was no mention of the journal with the greatest number of publications on the subject, since the articles were identified in 10 different journals.

Regarding the level of evidence of the studies, an article with level I (10\%) was identified; one with level II (10\%); a level III survey (10\%). Two articles (20\%) presented level IV of evidence. Three level V (30\%) and two (20\%) were classified as level VI.
The studies analyzed were organized in a synoptic chart, containing title; year/country; outlining/number of patients; interventions and outcomes, as shown in Chart 3.

The results show that the main DRPs in the transitional care from hospital to home are related to Drug Discrepancy and Reconciliation (40\%); Medication Adherence (MA) (30\%); and Adverse Drug Events (ADE) (30\%).

Among the themes identified in the selected articles, polypharmacy; the increase of drugs prescribed during hospitalization and/ or modification of the therapeutic regimen; incomplete/inaccurate/ illegible; lack of knowledge of prescribed medications; forgetfulness; and adverse reactions are important aspects regarding DRPs and that nurses in CT of elderly patients should consider.

Chart 3 - Summary of articles included in the integrative review, N=10, 2018

\begin{tabular}{|c|c|c|c|c|}
\hline Title & $\begin{array}{c}\text { Year/ } \\
\text { Country }\end{array}$ & $\begin{array}{l}\text { Outlining/ } \\
\text { Patients } \\
\text { number }\end{array}$ & Interventions & Outcomes \\
\hline $\begin{array}{l}\text { Multiple medication } \\
\text { use in older patients in } \\
\text { post-acute transitional } \\
\text { care: a prospective } \\
\text { cohort study }^{(18)}\end{array}$ & $\begin{array}{c}2014 \\
\text { Australia }\end{array}$ & $\begin{array}{c}\text { Prospective } \\
\text { Observational } \\
n=351\end{array}$ & $\begin{array}{l}\text { Comprehensive geriatric assessment, } \\
\text { performed at admission and discharge, } \\
\text { using the InterRAI Home Care } \\
\text { assessment tool. Outpatient abstracts } \\
\text { were coded using the World Health } \\
\text { Organization's Anatomical Therapeutic } \\
\text { Chemical (ATC) Classification System. }\end{array}$ & $\begin{array}{l}\text { Polypharmacy was observed in } 46.7 \% \text {, and } \\
\text { hyperpolypharmacy in } 39.2 \% \text { of patients. Increased } \\
\text { numbers of medications have been associated with } \\
\text { a greater number of chronic conditions, such as } \\
\text { Diabetes Mellitus, heart disease, lung disease and } \\
\text { dizziness. The most common drugs were analgesics } \\
(56.8 \%) \text { and gastric protectors ( } 52.7 \%) \text {. The most } \\
\text { common potentially inappropriate drugs were } \\
\text { tertiary tricyclic antidepressants. }\end{array}$ \\
\hline $\begin{array}{l}\text { Adverse Drug } \\
\text { Events Post-Hospital } \\
\text { Discharge in Older } \\
\text { Patients: Types, } \\
\text { Severity, and } \\
\text { Involvement of Beers } \\
\text { Criteria Medications }{ }^{(19)}\end{array}$ & $\begin{array}{l}2013 \\
\text { United } \\
\text { States }\end{array}$ & $\begin{array}{l}\text { Cross- } \\
\text { Sectional } \\
\text { Retrospective } \\
n=1000\end{array}$ & $\begin{array}{l}\text { Comprehensive analyzes of medical } \\
\text { records to identify possible drug-related } \\
\text { incidents during the } 45 \text {-day post- } \\
\text { hospital discharge period. }\end{array}$ & $\begin{array}{l}\text { At least one ADE was identified during the } 45- \\
\text { day period in } 18.7 \% \text { of participants. Of the } 115 \\
\text { ADEs identified, } 35 \% \text { were considered avoidable. } \\
32 \% \text { were characterized as severe and } 5 \% \text { as life } \\
\text { threatening. More than half of all ADEs occurred } \\
\text { within the first } 14 \text { days after hospitalization. }\end{array}$ \\
\hline $\begin{array}{l}\text { Predictors of } \\
\text { medication adherence } \\
\text { post-discharge: the } \\
\text { impact of patient age, } \\
\text { insurance status and } \\
\text { prior adherence }^{(20)}\end{array}$ & $\begin{array}{l}2012 \\
\text { United } \\
\text { States }\end{array}$ & $\begin{array}{l}\text { Randomized } \\
\text { Controlled } \\
\text { Study } \\
n=646\end{array}$ & $\begin{array}{l}\text { Survey of medical records and interview } \\
\text { for sociodemographic data collection, } \\
\text { cognition, health literacy level, medicine } \\
\text { in use, and adherence to medication } \\
\text { prior to admission. New telephone } \\
\text { interview } 30 \text { days post-discharge for } \\
\text { application of structured questionnaire } \\
\text { to measure the level of adherence to the } \\
\text { medication. }\end{array}$ & $\begin{array}{l}\text { The mean post-discharge adhesion index was } \\
95 \% \text {. For each increase of } 10 \text { years of age, there } \\
\text { was an absolute increase of } 1 \% \text { in adhesion. } \\
\text { Patients with private insurance were } 4.5 \% \text { less } \\
\text { adherent. Health literacy was not an independent } \\
\text { predictor of post-discharge adherence. }\end{array}$ \\
\hline $\begin{array}{l}\text { Relationship of Health } \\
\text { Literacy to Intentional } \\
\text { and Unintentional Non- } \\
\text { Adherence of Hospital } \\
\text { Discharge } \\
\text { Medications }\end{array}$ & $\begin{array}{c}2011 \\
\text { United } \\
\text { States }\end{array}$ & $\begin{array}{l}\text { Correlational } \\
\qquad \mathrm{n}=254\end{array}$ & $\begin{array}{l}\text { Interviews with patients before and after } \\
\text { discharge; application of the S-TOFHLA } \\
\text { tool; extraction of data from discharge } \\
\text { medical records; and coding of drug } \\
\text { discrepancies. }\end{array}$ & $\begin{array}{l}56 \% \text { presented a discrepancy between discharge } \\
\text { instructions and home use } 48 \text { hours post-discharge. } \\
\text { Subjects who did not receive guidelines showed no } \\
\text { adherence ( } 47.7 \%) \text { and those oriented were less likely } \\
\text { to non-adherence ( } 73.3 \%) \text {. Another common cause } \\
\text { of discrepancies was incomplete instructions (39.3\%). }\end{array}$ \\
\hline $\begin{array}{l}\text { Nurse Identified Hospital } \\
\text { to Home Medication } \\
\text { Discrepancies: } \\
\text { Implications for } \\
\text { Improving Transitional } \\
\text { Care }\end{array}$ & $\begin{array}{l}2010 \\
\text { United } \\
\text { States }\end{array}$ & $\begin{array}{c}\text { Randomized } \\
\text { Prospective } \\
n=101\end{array}$ & $\begin{array}{l}\text { Application of the electronic version of } \\
\text { the Medication Discrepancy Tool (MDT). }\end{array}$ & $\begin{array}{l}94 \% \text { of participants had at least one drug } \\
\text { discrepancy. The contributing causes were related } \\
\text { to the patient, with emphasis on non-intentional } \\
\text { medication adherence ( } 39.6 \%) \text {, with emphasis } \\
\text { on incomplete/inaccurate/illegible discharge } \\
\text { instructions (46.5\%). }\end{array}$ \\
\hline $\begin{array}{l}\text { Drug related problems } \\
\text { after discharge from an } \\
\text { Australian } \\
\text { teaching hospital }\end{array}$ & $\begin{array}{c}2010 \\
\text { Australia }\end{array}$ & $\begin{array}{l}\text { Documentary } \\
\text { Retrospective } \\
\text { Research } \\
n=76\end{array}$ & $\begin{array}{l}\text { Documentary research and data } \\
\text { grouping from discharge summary } \\
\text { analysis, home drug review reports and } \\
\text { home drug review. }\end{array}$ & $\begin{array}{l}\text { DRPs were identified in } 71 \text { patients }(93.3 \%) \text {, with } 398 \\
\text { problems and an average of } 5.6 \text { problems / patient. } \\
\text { The most frequent problems were uncertainty } \\
\text { about the drug's goal, potential interactions and } \\
\text { adverse reactions. }\end{array}$ \\
\hline $\begin{array}{l}\text { Adherencia al } \\
\text { tratamiento } \\
\text { farmacológico en } \\
\text { pacientes ancianos tras } \\
\text { el alta hospitalaria }\end{array}$ & $\begin{array}{l}2008 \\
\text { Spain }\end{array}$ & $\begin{array}{l}\text { Cross- } \\
\text { Sectional } \\
\text { Study } \\
n=70\end{array}$ & $\begin{array}{l}\text { Two home interviews ( } 3 \text { and } 20 \text { days } \\
\text { post-discharge) for the application of a } \\
\text { questionnaire containing quantitative and } \\
\text { qualitative data (sociodemographic data } \\
\text { and related to the use of prescribed drugs). }\end{array}$ & $\begin{array}{l}85 \% \text { of the medicines are used incorrectly, } \\
\text { mainly more than the prescribed ones }(67 \%) \text {. The } \\
\text { causes for misuse were forgetfulness and lack of } \\
\text { knowledge. The risk factors were: male gender, } \\
\text { live with children and more prescribed drugs. }\end{array}$ \\
\hline
\end{tabular}




\begin{tabular}{|c|c|c|c|c|}
\hline Title & $\begin{array}{c}\text { Year/ } \\
\text { Country }\end{array}$ & $\begin{array}{l}\text { Outlining/ } \\
\text { Patients } \\
\text { number }\end{array}$ & Interventions & Outcomes \\
\hline $\begin{array}{l}\text { Relationship of In- } \\
\text { Hospital Medication } \\
\text { Modifications of } \\
\text { Elderly Patients } \\
\text { to Postdischarge } \\
\text { Medications, } \\
\text { Adherence, and } \\
\text { Mortality }\end{array}$ & $\begin{array}{l}2008 \\
\text { Israel }\end{array}$ & $\begin{array}{l}\text { Retrospective } \\
\text { Prospective } \\
\text { Cohort Study } \\
\mathrm{n}=212\end{array}$ & $\begin{array}{l}\text { Clinical and demographic data, post- } \\
\text { discharge drug modifications, and } \\
\text { adherence were prospectively obtained } \\
\text { through patient interviews. Modifications } \\
\text { of the in-hospital drug regimen were } \\
\text { obtained retrospectively through medical } \\
\text { records. Professionals were occasionally } \\
\text { interviewed to clarify the reasons for drug } \\
\text { modifications. }\end{array}$ & $\begin{array}{l}\text { The rate of modification of the drug regimen } \\
\text { was } 49.8 \% \text {. Cognitively normal patients who } \\
\text { were admitted with polypharmacy and were } \\
\text { discharged home experienced fewer drug } \\
\text { modifications. Three months after discharge, } 17 \\
\text { patients died and } 50 \text { were readmitted. The main } \\
\text { risk factors were impaired cognition and chronic } \\
\text { disease. }\end{array}$ \\
\hline $\begin{array}{l}\text { Continuity and } \\
\text { Adherence to Long- } \\
\text { Term Drug Treatment } \\
\text { by Geriatric Patients } \\
\text { after Hospital } \\
\text { Discharge }^{(26)}\end{array}$ & $\begin{array}{l}2008 \\
\text { Israel }\end{array}$ & $\begin{array}{c}\text { Cohort } \\
\text { Prospective } \\
n=198\end{array}$ & $\begin{array}{l}\text { Clinical, demographic and drug data } \\
\text { were recorded for all patients, applying } \\
\text { the Mini-Mental State Examination } \\
\text { (MMSE) scale and pre-discharge } \\
\text { interview. After one month, the patient, } \\
\text { caregiver or doctor were interviewed } \\
\text { regarding the extent and reasons for } \\
\text { changes in the regimen of medication } \\
\text { and adherence to the treatment. }\end{array}$ & $\begin{array}{l}\text { An average post-discharge month, } 36.7 \% \text { of } \\
\text { patient medications had been modified in } \\
\text { comparison to the discharge prescription. To } \\
\text { improve adherence to the drug regimen, patients } \\
\text { should be encouraged to return to health } \\
\text { services. }\end{array}$ \\
\hline $\begin{array}{l}\text { Posthospital } \\
\text { medication } \\
\text { discrepancies: } \\
\text { prevalence and } \\
\text { contributing factors }^{(27)}\end{array}$ & $\begin{array}{l}2005 \\
\text { United } \\
\text { States }\end{array}$ & $\begin{array}{l}\text { Intervention } \\
\text { Research } \\
\mathrm{n}=375\end{array}$ & $\begin{array}{l}\text { Application of the Medication } \\
\text { Discrepancy } \\
\text { Tool (MDT). }\end{array}$ & $\begin{array}{l}14.1 \% \text { of the patients presented one or more } \\
\text { discrepancies. The discrepancy factors were } 50.8 \% \\
\text { associated with the patient and } 49.2 \% \text { associated } \\
\text { to the system. } 14.3 \% \text { of the patients who suffered } \\
\text { discrepancies were rehospitalized in } 30 \text { days. }\end{array}$ \\
\hline
\end{tabular}

\section{DISCUSSION}

Critical analysis of the selected articles revealed that the main DRPs in the transitional care of the elderly to the hospital are related to Drug Discrepancy and Reconciliation, MA, and ADE.

\section{Drug Discrepancy and Reconciliation}

Discrepancy can be defined as the difference between the medication prescribed by the doctor and the one the patient actually takes according to the medication bottles and patient description. It can also be defined as the lack of agreement between several drug regimens and medication errors that may occur in the transitional care from hospital to home $e^{(1,27-28)}$.

A study that explored the association between health literacy and drug discrepancies 48 hours after hospital discharge found that in $56 \%$ of the elderly, there were medication discrepancies during the commute from hospital to home ${ }^{(21)}$. Another study described the most common discrepancies identified by nurses. During home $\mathrm{CT}$, it was found that they were generalized in $94 \%$ of the elderly, with a mean of 3.3 discrepancies per participant ${ }^{(22)}$.

The types of drug discrepancies may be related to the patient and/ or the health system. Patient-related discrepancies present as nonvoluntary or involuntary adherence due to a number of factors, such as adverse drug reactions or side effects, intolerance, financial barriers, lack of knowledge about medications and real need for use $\mathrm{u}^{(22,27-29)}$.

Health system-related discrepancies may present as drug interactions or prescription of non-active drugs previously. They can also be presented as conflicting information from different sources of information; confusion between brand and generic names; incomplete/inaccurate/illegible discharge instructions; incorrect dose; incorrect amount; need for care not recognized by the health professional; and insufficient communication to other health care services to which the elderly are transferred ${ }^{(22,27-30)}$.
In a study conducted to determine the prevalence and factors associated with drug discrepancies in people 65 years of age or older, $58.8 \%$ of the discrepancies were related to the patient and $49.2 \%$ to the health system. According to this research, some classes of medications are prescribed more frequently. Therefore, they may account for $50 \%$ of all drug discrepancies occurring in the transitional care from hospital to home. These include anticoagulants (13\%), diuretics (10\%), angiotensin converting enzyme inhibitors (ACEI) (10\%), lipid-lowering agents (10\%) and proton pump inhibitors (7\%) $)^{(27)}$.

The most common drug classes associated with DRPs in the transitional care from hospital to home elderly include medications prescribed for cardiovascular disease, nervous system, and gastrointestinal and metabolic systems ${ }^{(23)}$.

Drug Reconciliation (DR) programs can be a useful strategy to reduce discrepancies in the patient's transitional care from hospital to home. DR is one of the operational procedures recommended by the High 5's Project - an international project launched by the World Health Organization (WHO) in 2006 to facilitate the deployment and evaluation of standardized solutions for patient safety. It is a complete evaluation of the patient's drug therapy, whenever treatment changes occur, to avoid medication errors, such as omissions, duplications, dose errors or drug interactions. Also to observe patterns of medication adherence treatment ${ }^{(22,31-32)}$.

The multidisciplinary team plays a fundamental role in the CT of the elderly, aiming at simplifying the post-discharge medication regimen and reducing DRPs. The nurse acts as coordinator of care and is responsible for ensuring safe the transitional care, and can collaborate in the development of care activities, such as discharge planning; implementation of protocols; use of checklists; orientations, appointment scheduling; follow-up before discharge; health education activities; post-discharge home visits; and post-discharge follow-up phone calls $s^{(22,30-31,33)}$. 


\section{Medication Adherence}

AM can be described as the degree of acceptance of a person in relation to the doctor, nurse or other health professional's guidelines. Adherence expresses understanding and cooperation, implying active behavior on the part of the patient and suggesting a collaborative involvement in the process of planning and implementing their treatment ${ }^{(4,34-35)}$.

About MA, a survey verified that only $8.6 \%$ of the elderly patients correctly performed the medical treatment after hospital discharge. $85 \%$ of the prescribed drugs were being used incorrectly, mostly, more than planned (67\%), below the prescribed one (33\%).54\% did not follow the recommendations on schedules and the relationship of medication use with meals. The most frequent causes identified by patients not taking the medication properly were forgetfulness and lack of knowledge. According to this study, there is little information on adherence in elderly patients after hospital discharge ${ }^{(24)}$.

MA cannot be treated in isolation within the context of health because it involves several factors that may be associated at the commute time. For WHO, adherence is a multidimensional phenomenon determined by the interaction of five factors: health system, socioeconomic factors, patient-related factors, diseaserelated factors, and treatment-related factors. In the case of the elderly, in many situations, their cognitive properties are affected and may result in difficulty in understanding and/or in the correct recall of their prescribed therapeutic regimens ${ }^{(4,20,24,35-36)}$.

The low degree of adhesion can adversely affect the clinical evolution and quality of life of the patient, constituting a relevant problem that can have personal, social and economic consequences. This problem reinforces the need for interventions to increase adherence to treatment, which implies a greater attention of the

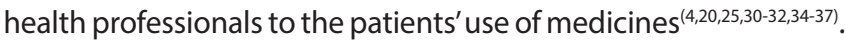

Evidence indicates that education and proper management of patients improve MA and increase self-care, presenting satisfactory clinical results and reduced medical expenses. It should be noted that adherence is a dynamic and continuous process, requiring nurses and other members of the health team, specific skills and well-outlined projects to act in $\mathrm{CT}^{(4,20,22,25,35-37)}$.

\section{Adverse Drug Events (ADE)}

ADE are common occurrences and have been the focus of studies in several countries, as they occur frequently and increase patients' morbidity and mortality, significantly increasing the costs of the health system. ADE can be considered as any damage presented by the patient that can be attributed to medications, and comprises the Adverse Drug Reaction (ADR) and Medication Error $(\mathrm{ME})^{(19,38)}$.

ADEs, especially those that can be prevented, represent a serious concern for the elderly during transitional care from hospital to home. This is a high-risk time. In addition to prescription errors, mistakes and confusions, may lead the patient to make the modification of the drug regimen on their own, with possible occurrence of $\mathrm{ADR}^{(38-39)}$.

The discharge planning, performed by the nurse, can be an opportunity to minimize the risks of ADE. At this moment, the nurse can perform the necessary guidelines, detect the characteristics of patients and their families and integrate them into the dynamics of the health-disease process. From this evaluation, nurses can identify care needs and simple risk factors, such as understanding medications, limitations of functional status, among other demands(33).

Regarding the evidence on this problem, at least one ADE (18.7\%) was identified in a study during the 45 -day post-discharge period of hospitalized elderly. Of the total ADE identified, 35\% were considered avoidable, $32 \%$ were characterized as severe and $5 \%$ as a life threat, and more than half of all ADEs occurred within the first 14 days after hospitalization ${ }^{(19)}$.

Polypharmacy can be considered as the use of five or more drugs, and may be an aggravating factor for the occurrence of $A D E$. The frequency of medication-related ADE is higher in the elderly, increasing expressively, according to the complexity of the therapy. The risk of occurrence increases by $13 \%$ with the use of two agents, increasing to 58\% when this number increases to five, rising to $82 \%$ in cases where seven or more drugs are consumed $^{(39)}$.

A study, when dealing with the extension of polypharmacy in the elderly in the transitional care from hospital to home, identified that $46.7 \%$ of the participants presented drug therapy with 5 to 9 drugs prescribed and $39.2 \%$ with 10 or more drugs prescribed $^{(38)}$. The potential repercussions of this use can be considered an important public health problem, since they are related to the increase of morbimortality ${ }^{(18)}$.

$\mathrm{WHO}$ has been encouraging all countries in the world to pay more attention to ADE and patient safety, and in many countries the discussions and implementations of strategies related to this issue are already well advanced. The discussion of this subject in Brazil is still embryonic, and the identification, classification and analysis of $A D E$, occurring in hospital institutions, are little publicized. Government actions regarding patient safety are still incipient, as there are few estimates on the incidence of ADE, their consequences, causes and direct and indirect costs of these errors for health organizations $s^{(4,19,38)}$.

The lack of knowledge about the ADE rate generates difficulties for managers to estimate the additional costs during hospitalization. It is represented by requests for additional examinations and addition of new medicines, in addition to the possibility of lawsuits brought by patients and family members. Insufficiency of financial resources, low pay, multiple working hours, inadequate technical preparation of workers, technological backwardness and other ills, suppose that in Brazil, ADEs have an important dimension with relevant human and material damages ${ }^{(5,38-39)}$.

\section{Study limitations}

The scarcity of research on DRPs in the elderly thematic during the critical period of the transitional care of the elderly from hospital to home, in Brazil, constituted a limitation of this study. However, part of this integrative review was research that portrays the reality of other countries that have already advanced in the discussions about the theme. Therefore, additional studies, including systematic observation of practices in institutions and interviews with professionals working in Brazilian health services, 
as well as of elderly patients who experience these commutes, will allow greater knowledge and expansion of information about the challenges experienced in public health in our country in the matter in question.

\section{Contributions to the Nursing field}

The relevance of this review is the presentation of the synthesis of ten primary studies that discuss important issues about DRPs in the transitional care of the elderly from hospital to home. It brings a set of evidences that can guide the actions of nursing and the public policies directed to this priority group.

DRPs theme can contribute to nursing care practice, considering that it involves complex issues related to care for patients in the transitional care between health services and/or home. Drug Discrepancies, ADE and MA are critical points during the transitional care. The focus of these aspects may contribute to patient safety and to the improvement of discharge planning performed by the nurse.

\section{FINAL CONSIDERATIONS}

Evidence has shown that drug discrepancies, ADE and MA can trigger DRPs and should be addressed by nursing as a key issue for the quality of the transitional care of the elderly from hospital to home.

MR was evidenced as a coherent and effective strategy to reduce DRPs, and may be an important tool for nursing CT. However, its effectiveness is related to the continuity of care in the process of hospital discharge to care performed at the patient's home, along with the caregivers.

New research regarding CT can be developed with the objective of quantifying and qualifying the nurse's role in the coordination, continuity of care and health education in the SUS, both at the hospital level and in PHC.

\section{REFERENCES}

1. Quinalha JV, Correr CJ. [Tools for assessing the pharmacotherapy of the elderly: a review]. Rev Bras Geriatr Gerontol [Internet]. 2010 [cited 2018 Jan 02];13(3):487-99. Available from: http://www.scielo.br/pdf/rbgg/v13n3/a14v13n3.pdf Portuguese.

2. Coleman EA, Parry C, Chalmers S, Min SJ. The care transitions intervention: results of a randomized controlled trial. JAMA Intern Med[Internet]. 2006 [cited 2017 Oct 20]1;(166):1822-28. Available from: https://jamanetwork.com/journals/jamainternalmedicine/fullarticle/410933

3. Ministério da Saúde (BR). Departamento de Assistência Farmacêutica e Insumos Estratégicos. Cuidado farmacêutico na Atenção Básica: Caderno 1 [Internet]. 2014 [cited 2018 Jan 02]. 108 p. Available from: http://bvsms.saude.gov.br/bvs/publicacoes/servicos_farmaceuticos_ atencao_basica_saude.pdf. Portuguese.

4. Marques LFG, Romano-Lieber NS. [Patient safety strategies for safe use of medications after hospital discharge]. Physis [Internet]. 2014 [cited 2017 Oct 14];24(2):401-20. Available from: http://www.scielo.br/pdf/physis/v24n2/0103-7331-physis-24-02-00401.pdf Portuguese.

5. Trompeter JM, McMillan AN, Rager ML, Fox JR. Medication discrepancies during transitions of care: a comparison study. J Healthc Qual [Internet]. 2014 [cited 2018 Jan 02];s1062-2551. Available from: http://onlinelibrary.wiley.com/doi/epdf/10.1111/jhq.12061

6. Instituto Brasileiro de Geografia e Estatística-IBGE. Perfil dos idosos responsáveis pelos domicílios. [Internet]. 2018 [cited 2017 Nov 01$].$ Available from: https://ww2.ibge.gov.br/home/presidencia/noticias/25072002pidoso.shtm

7. Marques LFG, Romano-Lieber NS. [Patient safety and medication use after discharge: exploratory study]. Saúde Soc [Internet]. 2014 [cited 2017 Oct 06];23(4):1431-44. Available from: http://www.scielo.br/pdf/sausoc/v23n4/0104-1290-sausoc-23-4-1431.pdf Portuguese.

8. Weber LAF, Lima MAD, Acosta AM, Marques GQ. [Care Transition fron hospital to home: Integrative Review]. Cogitare Enferm [Internet]. 2017[cited 2018 Jan 02];3(22):e47615. Available from: https://lume.ufrgs.br/handle/10183/173925 Portuguese.

9. Delatorre PG, Sá SPC, Valente GSC, Silvino ZR. [Planning for hospital discharge as a strategy for nursing care: integrative review]. Rev Enferm UFPE [Internet]. 2013[cited 2017 Nov 04];7(12 suppl). Available from: https://periodicos.ufpe.br/revistas/revistaenfermagem/article/ view/12387/15148 Portuguese.

10. Coleman EA, Boult C, American Geriatrics Society Health Care Systems Committee. Improving the quality of transitional care for persons with complex care needs. J Am Geriatr Soc [Internet]. 2003 [cited 2018 Jan 02];51(4):556-7. Available from: https://onlinelibrary.wiley.com/ doi/epdf/10.1046/j.1532-5415.2003.51186.x

11. Acosta AM, Lima MADS. [Usuários frequentes de serviço de emergência: fatores associados e motivos de busca por atendimento]. Rev Latino-Am Enfermagem [Internet]. 2015 [cited 2019 Apr 20];23(2):33744 Available from: https://www.lume.ufrgs.br/bitstream/ handle/10183/129910/000977080.pdf?sequence=1 Portuguese.

12. Naylor M, Keating, SA. Transitional care: moving patients from one care setting to another. Am J Nurs[Internet]. 2008 [cited 2018 Jan 02];108(9):58-63. Available from: https://www.ncbi.nlm.nih.gov/pmc/articles/PMC2768550/pdf/nihms107161.pdf

13. Whittemore R, Knafl K. The integrative review: updated methodology. J Adv Nurs[Internet]. 2005 [cited 2018 Jan 02];52(5):546-53. Available from: https://onlinelibrary.wiley.com/doi/epdf/10.1111/j.1365-2648.2005.03621.x.

14. Mendes KDS, Silveira RCCP, Galvão CM. [Integrative literature review: a research method to incorporate evidence in health care and nursing]. Texto Contexto Enferm [Internet]. 2008 [cited 2018 Jan 18];17(4):758-64. Available from: http://www.scielo.br/pdf/tce/v17n4/18. pdf Portuguese.

15. Souza MT, Silva MD, Carvalho R. [Integrative review: what is it? How to do it?]. Einstein [Internet]. 2010 [cited 2017 Oct 14];8(1 Pt1):102-6. 
Available from: http://www.scielo.br/pdf/eins/v8n1/pt_1679-4508-eins-8-1-0102 Portuguese.

16. Coleman EA, Smith JD, Frank JC, Eilertsen TB, Thiare JN, Kramer AM. Development and testing of a measure designed to assess the quality of care transitions. Int J Integr Care [Internet]. 2002 [cited 2018 Jan 02];2:1-9. Available from: https://www.ncbi.nlm.nih.gov/pmc/articles/ PMC1480381/pdf/ijic2002-200202.pdf

17. Melnyk BM, Fineout-Overholt E. Making the case for evidence-based practice. In: Melnyk BM, Fineout-Overholt E. Evidence-based practice in nursing \& healthcare: a guide to best practice. Philadelphia: Lippincot Williams \& Wilkins; 2005. p. 3-24.

18. Runganga M, Peel NM, Hubbard RE. Multiple medication use in older patients in post-acute transitional care: a prospective cohort study. Clin Interv Aging [Internet]. 2014[cited 2017 Oct 24];(9):1453-62. Available from: https://www.ncbi.nlm.nih.gov/pmc/articles/PMC4158998/ pdf/cia-9-1453.pdf

19. Kanaan AO, Donovan JL, Duchin NP, Field TS, Tjia J, Cutrona SL, et al. Adverse drug events post-hospital discharge in older patients: types, severity, and involvement of beers criteria medications. J Am Geriatr Soc [Internet]. 2013[cited 2017 Oct 20];61(11):1894-99. Available from: https://www.ncbi.nlm.nih.gov/pmc/articles/PMC4446728/pdf/nihms517947.pdf

20. Cohen MJ, Shaykevich S, Cawthon C, Kripalani S, Paasche-Orlow MK, Schnipper JL. Predictors of medication adherence post-discharge: the impact of patient age, insurance status and prior adherence. J Hosp Med [Internet]. 2012 [cited 2017 Oct 16];7(6):470-5. Available from: https://www.ncbi.nlm.nih.gov/pmc/articles/PMC3575732/pdf/nihms434410.pdf

21. Lindquist LA, Go L, Fleisher JV, Jain N, Friesema E, Baker DW. Relationship of health literacy to intentional and unintentional non-adherence of hospital discharge medications. J Gen Intern Med [Internet]. 2011 [cited 2018 Jan 02];27(2):173-8. Available from: https://www.ncbi.nlm. nih.gov/pmc/articles/PMC3270238/pdf/11606_2011_Article_1886.pdf

22. Corbett CF, Setter SM, Daratha KB, Neumiller JJ, Wood LD. Nurse Identified Hospital to Home Medication Discrepancies: Implications for Improving Transitional Care. Geriatr Nurs [Internet]. 2010 [cited 2018 Jan 02];31(3):188-96. Available from: https://www.sciencedirect.com/ science/article/pii/S0197457210002028

23. Ellitt GR, Engblom E, Aslani P, Westerlund T, Chen TF. Drug related problems after discharge from an Australian teaching hospital. Pharm World Sci [Internet]. 2010 [cited 2018 Jan 02];(32):622-30. Available from: https://link.springer.com/content/ pdf/10.1007\%2Fs11096-010-9406-9.pdf

24. Castellano-Muñoz P, Miranda-Ruiz A, Sojo-González G, Perea-Milla E, García-Alegría JJ, Santos-Rubio MD. [Pharmacological treatment adherence by older patients after hospital discharge]. Enferm Clin. 2008;18(3):120-26. Spanish.

25. Mansur N, Weiss A, Beloosesky, Y. Relationship of in-hospital medication modifications of elderly patients to postdischarge medications, adherence, and mortality. Sage J[Internet]. 2008[cited 2018 Jan 02];42(6):783-9. Available from: https://journals.sagepub.com/doi/ pdf/10.1345/aph.1L070

26. Mansur N, Weiss A, Hoffman A, Gruenewald T, Beloosesky Y. Continuity and adherence to long-term drug treatment by geriatric patients after hospital discharge: a prospective cohort study. Drugs Aging. 2008;25(10):861-70. doi: 10.2165/00002512-200825100-00005

27. Coleman EA, Smith JD, Raha D, Min SJ. Posthospital medication discrepancies: prevalence and contributing factors. Arch Intern Med [Internet]. 2005 [cited 2018 Jan 02];165(16):1842-7. Available from: https://jamanetwork.com/journals/jamainternalmedicine/fullarticle/486693

28. Farley TM, Powell S, Farris KB, Carter BL. Effect of clinical pharmacist intervention on medication discrepancies following hospital discharge. Int J Clin Pharm [Internet]. 2014 [cited 2018 Jan 02];36(2):430-7. Available from: https://www.ncbi.nlm.nih.gov/pmc/articles/PMC4026363/ pdf/nihms-564716.pdf

29. Stitt DM, Elliott DP, Thompson SN. Medication discrepancies identified at time of hospital discharge in a geriatric population. Am J Geriatr Pharmacother [Internet]. 2011 [cited 2018 Jan 02];9(4):234-40. Available from: https://www.sciencedirect.com/science/article/pii/ S1543594611001152?via\%3Dihub

30. Midlov P, Bahrani L, Seyfali M, Hoglund P, Rickhag E, Eriksson T. The effect of medication reconciliation in elderly patients at hospital discharge. Int J Clin Pharm [Internet]. 2012 [cited 2018 Jan 02];(34):113-9. Available from: https://link.springer.com/content/ pdf/10.1007\%2Fs11096-011-9599-6.pdf

31. Karapinar-Çarkit F, Borgsteede SD, Zoer J, Siegert C, Tulder M, Egberts AC, et al. The effect of the COACH program (Continuity of Appropriate pharmacotherapy, patient counselling and information transfer in Healthcare) on readmission rates in a multicultural population of internal medicine patients. BMC Health Serv Res [Internet]. 2010 [cited 2017 Oct 24];10(39). Available from: https://www.ncbi.nlm.nih.gov/pmc/ articles/PMC2843699/pdf/1472-6963-10-39.pdf

32. Saavedra-Quirós V, Montero-Hernández E, Menchén-Viso B, Santiago-Prieto E, Bermejo-Boixareu C, Hernán-Sanz J, et al. Conciliación de la medicación al ingreso y alta hospitalaria: una experiencia consolidada. Rev Calid Asist [Internet]. 2016 [cited 2018 Jan 02];31(S):45-54. Available from: https://www.elsevier.es/es-revista-revista-calidad-asistencial-256-pdf-S1134282X16300227

33. Cieto BB, Garbuio DC, Camargo VB, Napoleão AA. Nursing resources and innovations for hospital discharge: an integrative review. Rev Min Enferm [Internet]. 2014 [cited 2017 Oct 20] 18(3):752-57. Available from: http://www.reme.org.br/artigo/detalhes/960

34. Rocha CH, Oliveira APS, Ferreira C, Faggiani FT, Schroeter G, Souza ACA, et al. Medication adherence of elderly in Porto Alegre, RS. Cienc Saude Colet [Internet]. 2008 [cited 2017 Oct 14];13(Sup):703-10. Available from: http://www.redalyc.org/pdf/630/63009717.pdf

35. Almeida HO, Versiani EV, Dias AR, Carvalho MR, Novaes G, Trindade EMV. Treatment adherence among the elderly. Com Ciencias Saude [Internet]. 2007 [cited 2017 Oct 16];18(3):57-67. Available from: http://www.escs.edu.br/pesquisa/revista/2007Vol18_1art07adesao.pdf Portuguese. 
36. World Health Organization. Adherence to long-term therapies: evidence for action [Internet]. World Health Organization; 2003 [cited 2017 Oct 16]. 199 p. Available from: https://apps.who.int/medicinedocs/pdf/s4883e/s4883e.pdf

37. Teixeira JPDS, Rodrigues MCS, Machado VB. Patient education on drug treatment regimen in the process of hospital discharge: an integrative review. Rev Gaucha Enferm [Internet]. 2012 [cited 2017 Oct 16];33(2):186-196. Available from: http://www.scielo.br/pdf/rgenf/ v33n2/26.pdf Portuguese.

38. Silva AEBC, Reis AMM, Miasso Al, Santos JO, Cassiani SHB. Adverse drug events in a sentinel hospital in the State of Goiás, Brazil. Rev LatinoAm Enfermagem [Internet]. 2011 [cited 2017 Oct 20];19(2):1-9. Available from: http://www.scielo.br/pdf/rlae/v19n2/pt_21.pdf Portuguese.

39. Secoli SR. Polypharmacy: interaction and adverse reactions in the use of drugs by elderly people. Rev Bras Enferm [Internet]. 2010 [cited 2018 Jan 02];63(1):136-40. Available from: http://www.redalyc.org/pdf/2670/267019595023.pdf Portuguese. 